\title{
A Low Dose Euglycemic Infusion of Recombinant Human Insulin-like Growth Factor I Rapidly Suppresses Fasting-enhanced Pulsatile Growth Hormone Secretion in Humans
}

\author{
Mark L. Hartman, * Peter E. Clayton, * Michael L. Johnson, ${ }^{*}$ Abbie Celniker, \\ Andrew J. Perlman, ${ }^{5}$ K. G. M. M. Alberti, ' and Michael O. Thorner* \\ Departments of ${ }^{*}$ Medicine and ${ }^{\ddagger}$ Pharmacology, University of Virginia Health Sciences Center and National Science Foundation Center \\ for Biological Timing, Charlottesville, Virginia 22908; \$Genentech, Inc., South San Francisco, California 94080; and "Department of \\ Medicine, University of Newcastle Upon Tyne, Newcastle Upon Tyne, United Kingdom
}

\begin{abstract}
To determine if insulin-like growth factor I (IGF-I) inhibits pulsatile growth hormone (GH) secretion in man, recombinant human IGF-I ( rhIGF-I) was infused for $6 \mathrm{~h}$ at $10 \mu \mathrm{g} \cdot \mathrm{kg}^{-1} \cdot \mathrm{h}^{-1}$ during a euglycemic clamp in 10 normal men who were fasted for $32 \mathrm{~h}$ to enhance GH secretion. Saline alone was infused during an otherwise identical second admission as a control. As a result of rhIGF-I infusion, total and free IGF-I concentrations increased three- and fourfold, respectively. Mean GH concentrations fell from $6.3 \pm 1.6$ to $0.59 \pm 0.07 \mu \mathrm{g} /$ liter after $120 \mathrm{~min}$. GH secretion rates, calculated by a deconvolution algorithm, decreased with a $t_{1 / 2}$ of $16.6 \mathrm{~min}$ and remained suppressed thereafter. Suppression of GH secretion rates occurred within 60 min when total and free IGF-I concentrations were 1.6-fold and 2 -fold above baseline levels, respectively, and while glucose infusion rates were $<1 \mu \mathrm{mol} \cdot \mathrm{kg}^{-1} \cdot \mathrm{min}^{-1}$. During saline infusion, GH secretion rates remained elevated. Infusion of rhIGFI decreased the mass of GH secreted per pulse by $84 \%$ ( $P$ $<0.01$ ) and the number of detectable GH secretory pulses by $32 \%(P<0.05)$. Plasma insulin and glucagon decreased to nearly undetectable levels after $60 \mathrm{~min}$ of rhIGF-I. Serum free fatty acids, $\beta$-hydroxybutyrate, and acetoacetate were unaffected during the first $3 \mathrm{~h}$ of rhIGF-I but decreased thereafter to 52,32 , and $50 \%$ of levels observed during saline. We conclude that fasting-enhanced GH secretion is rapidly suppressed by a low-dose euglycemic infusion of rhIGF-I. This effect of rhIGF-I is likely mediated through IGF-I receptors independently of its insulin-like metabolic actions. (J. Clin. Invest. 1993. 91:2453-2462.) Key words: pituitary gland • deconvolution • metabolism • insulin • glucagon
\end{abstract}

\section{Introduction}

Insulin-like growth factor I ( IGF-I $)^{1}$ is a 70 -amino acid peptide that has $\sim 50 \%$ homology with proinsulin (1). The primary

This work was presented in part at the 73rd Annual Meeting of the Endocrine Society, Washington, D.C., 19-22 June 1991 (abstract no. 1609).

Address correspondence and reprint requests to Dr. Michael $\mathrm{O}$. Thorner, Department of Medicine, University of Virginia Health Sciences Center, Box 511-66, Charlottesville, VA 22908.

Received for publication 16 March 1992 and in revised form 23 November 1992

J. Clin. Invest.

(C) The American Society for Clinical Investigation, Inc.

$0021-9738 / 93 / 06 / 2453 / 10 \$ 2.00$

Volume 91, June 1993, 2453-2462 function of IGF-I is to mediate some of the growth-promoting actions of growth hormone $(\mathrm{GH})$, although it also has some insulin-like metabolic effects (2). Plasma IGF-I, derived primarily from hepatic synthesis under regulation by $\mathrm{GH}$, may function as a classical endocrine hormone to stimulate new bone formation and organ growth $(1,2)$. Alternatively, IGF-I may promote growth by a paracrine action since IGF-I is synthesized in many nonhepatic tissues, including the epiphyseal growth plate $(1,2)$. IGF-I circulates bound to several binding proteins that prolong the plasma half-life of IGF-I and modulate its bioavailability and action (3).

$\mathrm{GH}$ is secreted by the anterior pituitary gland in a pulsatile fashion under the regulation of two hypothalamic peptides: GH-releasing hormone (GHRH) stimulates GH synthesis and secretion whereas somatostatin inhibits $\mathrm{GH}$ release (4). Studies in rats, sheep, and humans indicate that whereas GHRH is required for the initiation of $\mathrm{GH}$ pulses, the amplitude of $\mathrm{GH}$ pulses is modulated by somatostatin (5-7). In humans, these interactions result in a pattern of volleys of $\mathrm{GH}$ secretory pulses with intervening periods of relative secretory quiescence (8). A role for IGF-I in the negative feedback regulation of GH secretion was first suggested by intracerebroventricular (ICV) injections of IGF preparations in rats that markedly diminished the amplitude of $\mathrm{GH}$ pulses in peripheral blood $(9,10)$. These early IGF preparations may have contained both IGF-I and IGF-II since a combination of both recombinant human IGF-I (rhIGF-I) and IGF-II (rhIGF-II) was required to reproduce these observations in recent experiments (11). In vitro, IGF-I decreases GH secretion and mRNA levels in cultured rat pituitary cells (12). In studies with incubated rat hypothalami, IGF-I has been reported to increase somatostatin secretion (13, 14 ) and mRNA levels (14); GHRH release was increased in one study (14) and decreased in another (15). In studies using the GH-deficient dwarf rat, ICV IGF-I infusions over $7 \mathrm{~d}$ increased somatostatin and decreased GHRH mRNA; this effect was not observed with systemic infusions (16). Thus, in rats, IGF-I directly inhibits GH secretion by the pituitary gland and may also influence $\mathrm{GH}$ secretion via effects on the hypothalamus in combination with IGF-II.

Since many species differences in the regulation of $\mathrm{GH}$ secretion exist it is important to determine whether IGF-I inhibits GH secretion in man. Clinical investigations of rhIGF-I effects in man have focused primarily on its metabolic actions,

1. Abbreviations used in this paper: AcAc, acetoacetate; $\mathrm{BOH}, \beta$-hydroxybutyrate; $\mathrm{CV}$, coefficient of variation; $\mathrm{GH}$, growth hormone; GHRH, GH-releasing hormone; ICV, intracerebroventricular; IGFBP, IGF-binding protein; $\mathrm{L}_{\mathrm{v}}$, liter of distribution volume; rhIGF-I, recombinant human IGF-I. 
although some information about its effect on GH secretion has been gleaned. Bolus injections of rhIGF-I caused hypoglycemia and stimulated GH secretion (17). However, if hypoglycemia was avoided by food ingestion, then rhIGF-I infusions suppressed serum $\mathrm{GH}$ concentrations after $6 \mathrm{~d}$ in one of two subjects (18) and after $2 \mathrm{~d}$ in six subjects (19). The timing and frequency of blood sampling in these studies was insufficient to assess the time course of effects of rhIGF-I on pulsatile GH secretion. Furthermore, subjects received mixed meals, which may have unpredictable effects on GH release since carbohydrates suppress and some amino acids stimulate $\mathrm{GH}$ release (4). The purpose of this study was to investigate the effect of IGF-I on pulsatile GH secretion in man using methods that would circumvent the confounding factors identified in previous studies. We infused a low dose of rhIGF-I ( 10 $\mu \mathrm{g} \cdot \mathrm{kg}^{-1} \cdot \mathrm{h}^{-1}$ ) during a simultaneous euglycemic clamp (20) in subjects fasted for $32 \mathrm{~h}$ to increase $\mathrm{GH}$ secretion $(21,22)$; blood samples were obtained at 5-min intervals for $8 \mathrm{~h}$ and GH secretion rates were estimated by deconvolution analysis (23). We report that fasting-enhanced pulsatile GH secretion is rapidly suppressed by a low-dose rhIGF-I infusion, which stimulates minimal glucose uptake, suppresses insulin and glucagon levels rapidly, and has a delayed antilipolytic effect.

\section{Methods}

\section{Subjects and study design}

The study was approved by the Human Investigation and General Clinical Research Center Advisory Committees of the University of Virginia. 10 healthy men (ages 21-36 yr) of normal body weight (body mass indexes $20.8-26.6 \mathrm{~kg} / \mathrm{m}^{2}$ ) were studied after written informed consent. All were nonsmokers, were taking no medications, had not undertaken transmeridian travel for $\geq 4 \mathrm{wk}$, and had unremarkable clinical histories and physical examinations. All had normal biochemical indexes of renal, hepatic, and hematologic function and normal fasting serum concentrations of glucose, glycated hemoglobin, IGF-I, thyroxine $\left(\mathrm{T}_{4}\right)$, thyroid stimulating hormone $(\mathrm{TSH})$, prolactin, luteinizing hormone ( $\mathrm{LH})$, and follicle stimulating hormone (FSH). The subjects were studied on two occasions separated by $\geq 4 \mathrm{wk}$ and took ferrous sulfate between study days. For each study, the subjects fasted for $40 \mathrm{~h}$ during which they ingested only water, potassium chloride ( 20 $\mathrm{meq} / \mathrm{d}$ ), and a multivitamin tablet. Compliance with the fast was monitored by daily weights and measurement of urine ketones. Daily blood samples ( 0800 hours) were obtained for complete blood count, serum chemistries, and hepatic enzymes to monitor for adverse effects of the fast. The studies were performed on day 2 of the fast (32-40 h of fasting). The subjects received infusions of rhIGF-I and $20 \%$ dextrose during the first admission and normal saline during the second admission.

Admission 1: rhIGF-I infusion with euglycemic clamp. At 0600 hours on day 2 of the fast, two intravenous cannulas were placed anterograde in an antecubital vein for the continuous infusions of test substances and retrograde in a wrist vein for blood sampling. The latter was kept patent by a slow saline infusion and the hand was kept in a heated box at $70^{\circ} \mathrm{C}$ to ensure arterialization of venous blood (20). The rhIGFI (Genentech, Inc., South San Francisco, CA) was prepared as a 0.19$\mathrm{mg} / \mathrm{ml}$ solution in normal saline. From 0800 to 1600 hours, arterialized venous blood samples for measurement of $\mathrm{GH}$ and glucose ( 1.5 $\mathrm{ml})$ were obtained at 5 -min intervals and samples $(11.0 \mathrm{ml})$ for total and free IGF-I, insulin, glucagon, $\beta$-hydroxybutyrate (BOH), acetoacetate (AcAc), and FFA concentrations were obtained every 15 min during the first hour of the infusion and every $30 \mathrm{~min}$ for the remainder of the infusion. All serum samples were frozen at either -20 or $-70^{\circ} \mathrm{C}$ until analyzed. At 1000 hours (time $=0 \mathrm{~min}$ ), a 5 -min priming infusion $\left(20 \mu \mathrm{g} \cdot \mathrm{kg}^{-1} \cdot \mathrm{h}^{-1}\right)$ followed by a continuous infusion (10 $\mu \mathrm{g} \cdot \mathrm{kg}^{-1} \cdot \mathrm{h}^{-1}$ ) of rhIGF-I was started. Plasma glucose concentrations were maintained at basal levels by a variable $20 \%$ dextrose infusion that was adjusted every $5 \mathrm{~min}$ on the basis of plasma glucose measurements and a negative feedback algorithm (20). The actual glucose concentration of the $20 \%$ dextrose solution was measured for each experiment. A glucose analyzer (Beckman Analytical System Group, Columbia, MD) was used to measure plasma glucose concentrations rapidly during the clamp. The infusions were delivered by microprocessor pumps (model 22; Harvard Apparatus, South Natick, MA) that were controlled by a computer program (running on an IBM-compatible computer) written and kindly supplied by Dr. David Krusch (University of Rochester, Rochester, NY). Subjects remained supine and awake during the study. The infusions and blood sampling were terminated at $1600 \mathrm{~h}$ and the subjects were fed. The subjects were observed overnight for possible delayed hypoglycemic effects of rhIGF-I. The dose of rhIGF-I was chosen to minimize the amount of glucose infused to prevent hypoglycemia; previous investigators had fed subjects $2,500 \mathrm{kcal} / \mathrm{d}$ to avoid hypoglycemia during an infusion of $20 \mu \mathrm{g} \cdot \mathrm{kg}^{-1} \cdot \mathrm{h}^{-1}(18)$. The rhIGFI infusion and euglycemic clamp were continued for $6 \mathrm{~h}$ to optimize our observations of effects on pulsatile GH secretion.

Admission 2: saline infusion. As a control, the subjects were studied on a second occasion using the same protocol as Admission 1 except that an infusion of normal saline, matched to the volume of the previous $20 \%$ dextrose and rhIGF-I infusions, was administered. The subjects were fed at 1600 hours and then discharged.

\section{Assays}

Growth hormone. Serum GH concentrations were measured in duplicate by immunoradiometric assay using standards diluted in human serum (Nichols Institute, San Juan Capistrano, CA). The sensitivity of the assay was $0.2 \mu \mathrm{g} /$ liter; samples with $<0.2 \mu \mathrm{g} /$ liter $\mathrm{GH}$ were set equal to $0.2 \mu \mathrm{g} /$ liter for statistical analyses. The mean intra- and interassay coefficients of variation (CV) were 8.4 and $8.0 \%$, respectively.

Total and free IGF-I. Total plasma IGF-I was measured by RIA after acid ethanol extraction. The concentration of free IGF-I in plasma was measured by RIA after size-exclusion chromatography. These methods, previously published in brief form (24), are described in detail here.

Acid ethanol extraction for total IGF-I quantitation. To dissociate IGF-I from IGF-binding proteins (IGFBP) before RIA, plasma samples were extracted with acid ethanol according to a modification of the method of Daughaday et al. (25). One part plasma sample was mixed with four parts acid ethanol (12.5\% $2 \mathrm{~N} \mathrm{HCI}, 87.5 \%$ ethanol, 200 proof) and allowed to incubate on ice for $30 \mathrm{~min}$. The samples were then microcentrifuged for $5 \mathrm{~min}$ in a Fisher microfuge model 235C; (Fisher Scientific Co., Pittsburgh, PA); the supernatant was removed and neutralized by adding one part of $1 \mathrm{M}$ Tris base buffer, $\mathrm{pH} 9.5$, to five parts of supernatant. These samples were then diluted 1:10 in the assay diluent described below for RIA. The recovery of IGF-I in the RIA after acid ethanol extraction was $>80 \%$.

Chromatographic separation of free IGF-I. Size-exclusion HPLC (SE-HPLC) was used to separate free IGF-I from IGF-I complexed with binding proteins; a $2.5 \times 30 \mathrm{~cm}$ TSK-G2000SW column (HPGenenchem, South San Francisco, CA) and a mobile phase of 0.2 $M$ sodium phosphate, $0.05 \%$ polysorbate ( Tween) 20 (Sigma Chemical Co., St. Louis, MO), pH 6.5 was used. Samples were prefiltered using a 25-mm diameter, 0.22- $\mu \mathrm{m}$, Millex-GV filter (Millipore Corp., Bedford, MA) and for some samples a $7.5 \times 75 \mathrm{~mm}$ silica guard column (Bio-Rad Laboratories, Richmond, CA ) was used to reduce the effects of plasma proteins on the performance of the TSK-G2000SW column over time. The sample injection volume was $100 \mu$ l and a flow rate of 1 $\mathrm{ml} / \mathrm{min}$ was used. The HPLC system used was an isocratic pump system (series 410 Perkin Elmer Corp., Norwalk, CT) equipped with an automatic sample injection system. Fractions were collected $(0.5 \mathrm{ml})$ between 11 and $14 \mathrm{~min}$ after sample injection using a fraction collector (Foxy 200; Isco, Lincoln, NE). At the flow rate of $1 \mathrm{ml} / \mathrm{min}$, this was the time that corresponded to the elution of proteins with molecular masses between 17 (myoglobin) and $1.4 \mathrm{kD}$ (vitamin B-12), using the 
low molecular weight markers from Bio-Rad Laboratories. After chromatography, IGF-I concentrations were measured by RIA in the fractions where standard IGF-I would elute. The sum of the concentrations of IGF-I in these fractions was considered to be the free IGF-I concentration for a given sample. Fractions with undetectable quantities of IGF-I were set equal to the assay sensitivity. The dissociation of the most abundant IGF-I-IGFBP complexes by this method was shown to be negligible using recombinant IGF-I-IGFBP-3 complexes. The recovery of rhIGF-I added to plasma was expected to vary with the concentration of rhIGF-I and between individuals because of the presence of IGFBPs in plasma. For plasma samples containing 100, 250, and 500 $\mu \mathrm{g} /$ liter added rhIGF-I, the percent recovered as free IGF-I averaged 51,71 , and $80 \%$, respectively; this suggests increasing saturation of binding sites at the higher concentrations.

IGF-I RIA. For RIA, samples or standards ( rhIGF-I) were diluted in an assay diluent consisting of PBS containing $0.1 \%$ gelatin (Eastman Kodak Co., Rochester, NY), 0.05\% polysorbate (Tween) 20 (Sigma Chemical Co.) and $0.01 \%$ thimerosal (Sigma Chemical Co.). After addition of ${ }^{125}$ I-IGF-I tracer and a rabbit anti-human IGF-I antibody (provided by Peter Gluckman, Auckland, New Zealand), the tubes were incubated overnight at $2-8^{\circ} \mathrm{C}$; goat anti-rabbit IgG immunobeads (Bio-Rad Laboratories) were then added. A gamma counter (model 28023; Micromedic Systems Inc., Horsham, PA) with accompanying four-parameter curve-fitting software (version 1.51) was used to determine the sample values. For total IGF-I measurement (extraction + RIA), intra- and interassay CVs ranged from 2.4 to $7.0 \%$ and 12 to $19 \%$, respectively, for concentrations between 98 and $166 \mu \mathrm{g} /$ liter. Cross-reactivities of human IGF-II and insulin were 0.25 and $0.08 \%$, respectively. The sensitivity of this assay was $0.3 \mu \mathrm{g} /$ liter. The normal range for men aged 18-35 after an overnight fast in this assay is $31-240$ $\mu \mathrm{g} /$ liter (mean \pm SD: $132 \pm 49 \mu \mathrm{g} /$ liter, $n=76$; Genentech, Inc., unpublished observations). For free IGF-I measurement (SE-HPLC + RIA), interassay CVs were 6 and $17 \%$ for samples with mean recovered free IGF-I concentrations of 178 and $51 \mu \mathrm{g} /$ liter, respectively. The sensitivity of this assay was $1.6 \mu \mathrm{g} /$ liter; samples with $<1.6 \mu \mathrm{g} /$ liter free IGF-I were set equal to $1.6 \mu \mathrm{g} /$ liter for statistical analyses. In previous studies, the vast majority of men aged $18-35$ had undetectable free IGF-I concentrations after an overnight fast (reference 24 and Genentech, Inc., unpublished observations).

Other assays. Plasma insulin was measured by an RIA method with a sensitivity of $11 \mathrm{pmol} / \mathrm{L} \mathrm{(26);} \mathrm{the} \mathrm{interassay} \mathrm{CV} \mathrm{was} 11 \%$ at 49 $\mathrm{pmol} / \mathrm{L}$ and $5.9 \%$ at $100 \mathrm{pmol} / \mathrm{L}$. Plasma glucagon was measured by RIA after acetone extraction (27); the sensitivity of the assay was 10 $\mathrm{ng} / \mathrm{L}$ and the interassay $\mathrm{CV}$ was $12 \%$ at $44 \mathrm{ng} / \mathrm{L}$ and $21 \%$ at $19 \mathrm{ng} / \mathrm{L}$. This glucagon assay excludes "big plasma glucagon," which is not pancreatic in origin (27). Samples with undetectable amounts of the above hormones were assigned the value of the sensitivity of the assay for statistical analysis. Previously described methods were used to measure FFA, BOH, AcAc, prolactin, LH, and FSH (28-30). Hematology, serum chemistry, glycated hemoglobin, $\mathrm{T}_{4}$, and TSH measurements were performed in the Clinical Laboratories of the University of Virginia Health Sciences Center using routine methods.

\section{Deconvolution analysis of $G H$ secretion}

A waveform-independent deconvolution method was used to estimate endogenous GH secretion rates from the serial serum GH concentrations. This method, previously described in detail, calculates hormone secretion rates at each time point, given an estimated hormone $t_{1 / 2}$ and its associated variance, without making any assumptions about the nature of underlying hormone secretory events (23). A previously determined estimate of the two-component endogenous $\mathrm{GH} t_{1 / 2}$ was used for this analysis (mean $\pm \mathrm{SE}$ ): (a) first component, $3.5 \pm 0.7 \mathrm{~min} ;(b)$ second component, $20.7 \pm 0.7 \mathrm{~min} ;(c)$ fractional amplitude of the second component, $0.63(31)$. Calculated GH secretion rates and their statistical confidence intervals are expressed as $\mu \mathrm{g} /$ liter of distribution volume $\left(L_{v}\right)$ per $\min \left(\mu \mathrm{g} \cdot \mathrm{L}_{\mathrm{v}}{ }^{-1} \cdot \mathrm{min}^{-1}\right)$. Significant secretory pulses were identified by upstrokes and downstrokes with significant first derivatives ( $Z$ score of $>1.645$ for $P<0.05$ vs. noise) and at least two points that were significantly nonzero by the corresponding confidence intervals $(P<0.05 ; Z$ score $>1.645$ by one-tailed test $)(23)$. The mass of $\mathrm{GH}$ secreted per pulse $\left(\mu \mathrm{g} / \mathrm{L}_{\mathrm{v}}\right)$ was estimated as the area of the resolved secretory burst, defined as the mean GH secretory rate over the interval $\Delta t$ multiplied by $(\Delta t-5 \mathrm{~min})$. The mass of $\mathrm{GH}$ secreted during the 6-h period after the start of the infusions was estimated as the product of the mean $\mathrm{GH}$ secretion rate and the time interval (360 min).

\section{Group exponential analysis of $G H$ secretion rates}

To estimate the $t_{1 / 2}$ of suppression of GH secretion rates by rhIGF-I, deconvolution-resolved $\mathrm{GH}$ secretion rates were modeled as an exponential decay starting at 1000 hours (the starting time of the infusions). The serial GH secretion rates for all 10 subjects were individually fitted to a general exponential function, $F(t)=B+A e\left(^{-k t}\right)$, where $F(t)$ is the $\mathrm{GH}$ secretion rate at time $t, B$ is the baseline to which the function decays exponentially, $A$ is the amplitude, and $k$ is the rate constant. Since the amount of GH secreted varied among subjects, $A$ was resolved for each individual data set. However, since we desired to determine a weighted mean for $k$ and $B$, these variables were constrained to be constant for all 10 data sets. The estimation of these parameters, along with their associated $95 \%$ confidence limits, was carried out by nonlinear, least-squares iterative curve fitting, assuming asymmetric partially correlated joint parameter variance spaces, as described earlier (32). Parameter estimation was carried out using a modified GaussNewton quadratic convergence algorithm, in which the GH secretion rates were weighted inversely by the SD of the secretion rate at each 5 -min interval, as resolved by deconvolution analysis (23). The group exponential fit was considered significant if the disappearance rate constant, $k$, was significantly different from zero and if the group of amplitudes had a distribution of $\mathrm{Z}$ scores $(A / \mathrm{SD})$ that was nonrandom by the Kolmogorov-Smirnov test (33).

\section{Statistical analysis}

Results are expressed as means \pm SE. Since each subject served as his own control, paired comparisons between the results from the rhIGF-I and saline treatment days or between the baseline period and infusion period were made with the Wilcoxon signed rank test (33). When groups had unequal numbers of samples because of missing data, the Wilcoxon rank sum test was used for unpaired comparisons (33). All hypothesis testing was two sided. Statistical significance was assumed when $P \leq 0.05$, except where multiple comparisons were involved. In the latter case, the overall per study error rate was limited by restricting the per comparison $P$ value to $\leq 0.01$, as suggested by recent statistical reviews of this issue (34). However, when multiple comparisons were made over time, a $P$ of $\leq 0.05$ was accepted if a clear trend towards increasing statistical significance over time was evident (34).

\section{Results}

Total and free IGF-I concentrations. Baseline serum concentrations of total and free IGF-I on day 1 of both admissions ( after an 8-h overnight fast) were $96 \pm 10$ and $2.2 \pm 0.25 \mu \mathrm{g} /$ liter, respectively. These values were unchanged by an additional $24 \mathrm{~h}$ of fasting ( $95 \pm 5.9$ and $2.3 \pm 0.28 \mu \mathrm{g} /$ liter, respectively). Fig. 1 illustrates the changes in total and free IGF-I levels during the saline and rhIGF-I infusions. Total IGF-I concentrations during rhIGF-I infusion first became significantly different from those during saline infusion at $30 \mathrm{~min}(123 \pm 13$ vs. $89 \pm 4.8$ $\mu \mathrm{g} /$ liter, $P \leq 0.05$ ). Thereafter, total IGF-I levels gradually increased to $\sim 300 \mu \mathrm{g} /$ liter after $300-360 \mathrm{~min}$. During the baseline period (0800-1000 hours), free IGF-I concentrations were below the limit of assay sensitivity ( $1.6 \mu \mathrm{g} /$ liter ) in 66 and $69 \%$ of samples on the saline and rhIGF-I days, respectively; mean free IGF-I concentrations were $2.1 \pm 0.2 \mu \mathrm{g} /$ liter (saline day) and 2.4 $\pm 0.2 \mu \mathrm{g} /$ liter (rhIGF-I day) with no significant 

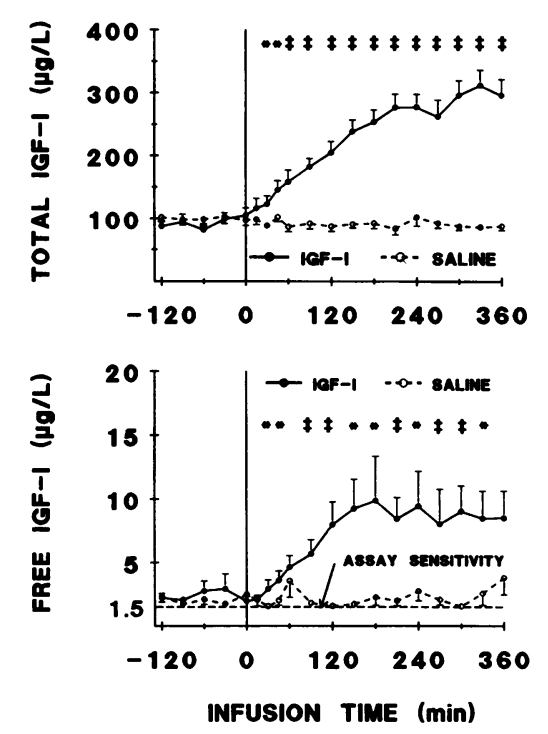

Figure 1. Mean ( \pm SE) serum total (top) and free (bottom) IGF-I concentrations measured in blood samples obtained for $2 \mathrm{~h}$ before and during 6-h infusions of rhIGF-I ( 10 $\left.\mu \mathrm{g} \cdot \mathrm{kg}^{-1} \cdot \mathrm{h}^{-1}\right)(\bullet)$ and saline (O) in 10 normal men on the second day of two separate fasts (32-40 $\mathrm{h}$ of fasting). The vertical line in each panel denotes the start of the infusions (time $=0 \mathrm{~min}$ ). Wilcoxon signed rank tests were used to test for differences between the rhIGF-I and saline treatments. ${ }^{*} P \leq 0.05$; ${ }^{\ddagger} P \leq 0.01$.

differences between the two study days. During infusion of rhIGF-I, free IGF-I concentrations gradually increased although there was considerable variability between individuals. Mean free IGF-I concentrations during rhIGF-I infusion first became significantly different from those during saline infusion at $30 \mathrm{~min}(2.9 \pm 0.72$ [rhIGF-I] vs. all samples $<1.6 \mu \mathrm{g} /$ liter [saline], $P \leq 0.05$ ), although a consistent difference from the variable baseline values was not evident until $90 \mathrm{~min}$. Thereafter, mean free IGF-I levels increased to $9.9 \pm 3.5 \mu \mathrm{g} /$ liter at $180 \mathrm{~min}$ and then declined slightly (but not significantly) to between 8 and $9 \mu \mathrm{g} /$ liter during the last $90 \mathrm{~min}$ of the infusion. In comparison, mean free IGF-I concentrations remained between 1.6 and $3.8 \mu \mathrm{g} /$ liter during the saline infusion. Paired comparisons with the Wilcoxon signed rank test revealed $P$ values $\leq 0.01$ or 0.05 at all but two time points after $30 \mathrm{~min}$.

Glucose concentrations and infusion rates. Plasma glucose concentrations at the start of the infusions averaged $4.7 \pm 0.15$ $\mathrm{mmol} / \mathrm{L}(84 \pm 2.8 \mathrm{mg} / \mathrm{dl})$. During rhIGF-I infusion, a euglycemic clamp maintained glucose concentrations within $10 \%$ of the baseline glucose value. Mean glucose concentrations expressed as a percentage of baseline values ranged between 98.6 and $101 \%$ for the 10 subjects $(99.6 \pm 0.27 \%)$. The CV for the glucose concentrations ranged between 2.9 and $7.0 \%$ $(4.7 \pm 0.48 \%)$. Mean glucose infusion rates during the rhIGF-I infusion and euglycemic clamp are shown in Fig. 2 . During the first hour minimal amounts of glucose were infused to maintain target glucose concentrations $\left(0.94 \pm 0.013 \mu \mathrm{mol} \cdot \mathrm{kg}^{-1}\right.$.

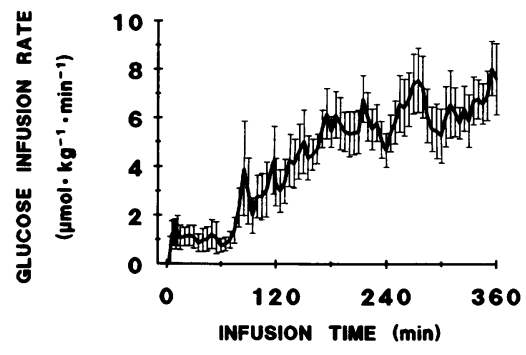

Figure 2. Mean ( \pm SE) glucose infusion rates required to maintain euglycemia during the rhIGF-I $(10$ $\left.\mu \mathrm{g} \cdot \mathrm{kg}^{-1} \cdot \mathrm{h}^{-1}\right)$ infusions. To convert $\mu \mathrm{mol} \cdot \mathrm{kg}^{-1} \cdot \mathrm{min}^{-1}$ to $\mathrm{mg} \cdot \mathrm{kg}^{-1} \cdot \mathrm{min}^{-1}$, multiply by 0.18 .

$\min ^{-1}$ or $\left.0.17 \pm 0.049 \mathrm{mg} \cdot \mathrm{kg}^{-1} \cdot \mathrm{min}^{-1}\right)$. During the next $3 \mathrm{~h}$ increasing amounts of glucose were infused until a near steady state was achieved during the last $2 \mathrm{~h} \quad(6.7 \pm 0.83$ $\mu \mathrm{mol} \cdot \mathrm{kg}^{-1} \cdot \mathrm{min}^{-1}$ or $\left.1.2 \pm 0.15 \mathrm{mg} \cdot \mathrm{kg}^{-1} \cdot \mathrm{min}^{-1}\right)$.

$G H$ concentrations and secretion rates. Individual serum GH concentrations during the $2-\mathrm{h}$ baseline period and the 6-h infusions of saline and rhIGF-I are shown in Fig. 3. During the baseline periods, $\mathrm{GH}$ concentrations were elevated as would be expected in subjects fasted for $32 \mathrm{~h}$. Random pulses of $\mathrm{GH}$ secretion were evident before and during both infusions. However, in all 10 subjects $\mathrm{GH}$ concentrations were lower during the last $4 \mathrm{~h}$ of rhIGF-I infusion than during saline. Mean GH concentrations and deconvolution-resolved secretion rates are depicted in Fig. 4. Mean GH concentrations fell from $6.3 \pm 1.6$ to $0.59 \pm 0.07 \mu \mathrm{g} /$ liter during the first $120 \mathrm{~min}$ of the rhIGF-I infusion. After $120 \mathrm{~min}$, mean $\mathrm{GH}$ concentrations remained $<0.6 \mu \mathrm{g} /$ liter, although small pulses of $\mathrm{GH}$ secretion were observed in eight subjects. Maximal GH concentrations after 120 min of rhIGF-I did not exceed $1 \mu \mathrm{g} /$ liter in six subjects; two subjects had GH peak values of 2-3 $\mu \mathrm{g} /$ liter (Fig. 3). Mean $\mathrm{GH}$ secretion rates, calculated by removing the effect of metabolic clearance with deconvolution analysis, fell rapidly during
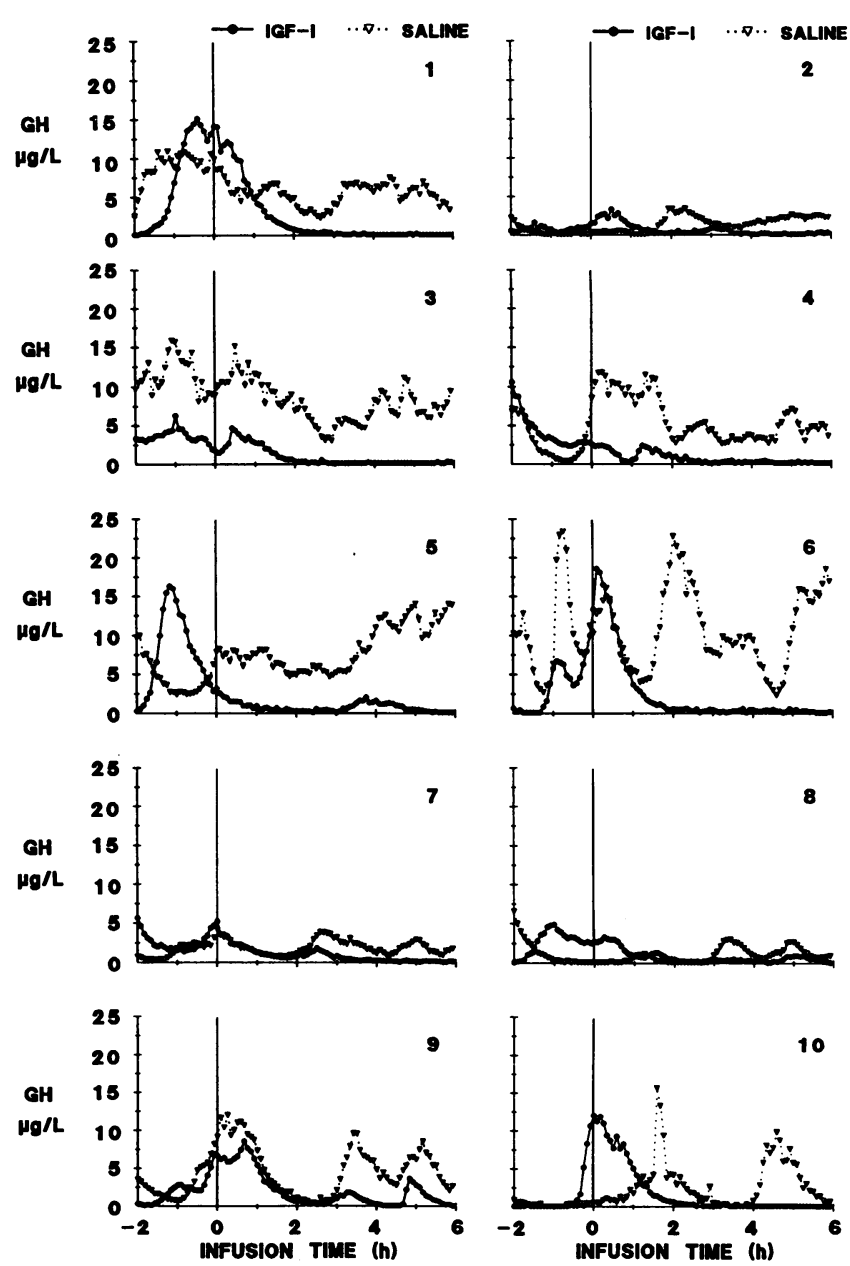

Figure 3. Individual serum GH concentrations measured in blood samples obtained at 5-min intervals on the rhIGF-I (•) and saline $(\nabla)$ days. The experimental protocol is described in the legend for Fig. 1. Note that rhIGF-I suppressed GH concentrations compared with saline in all 10 men. 

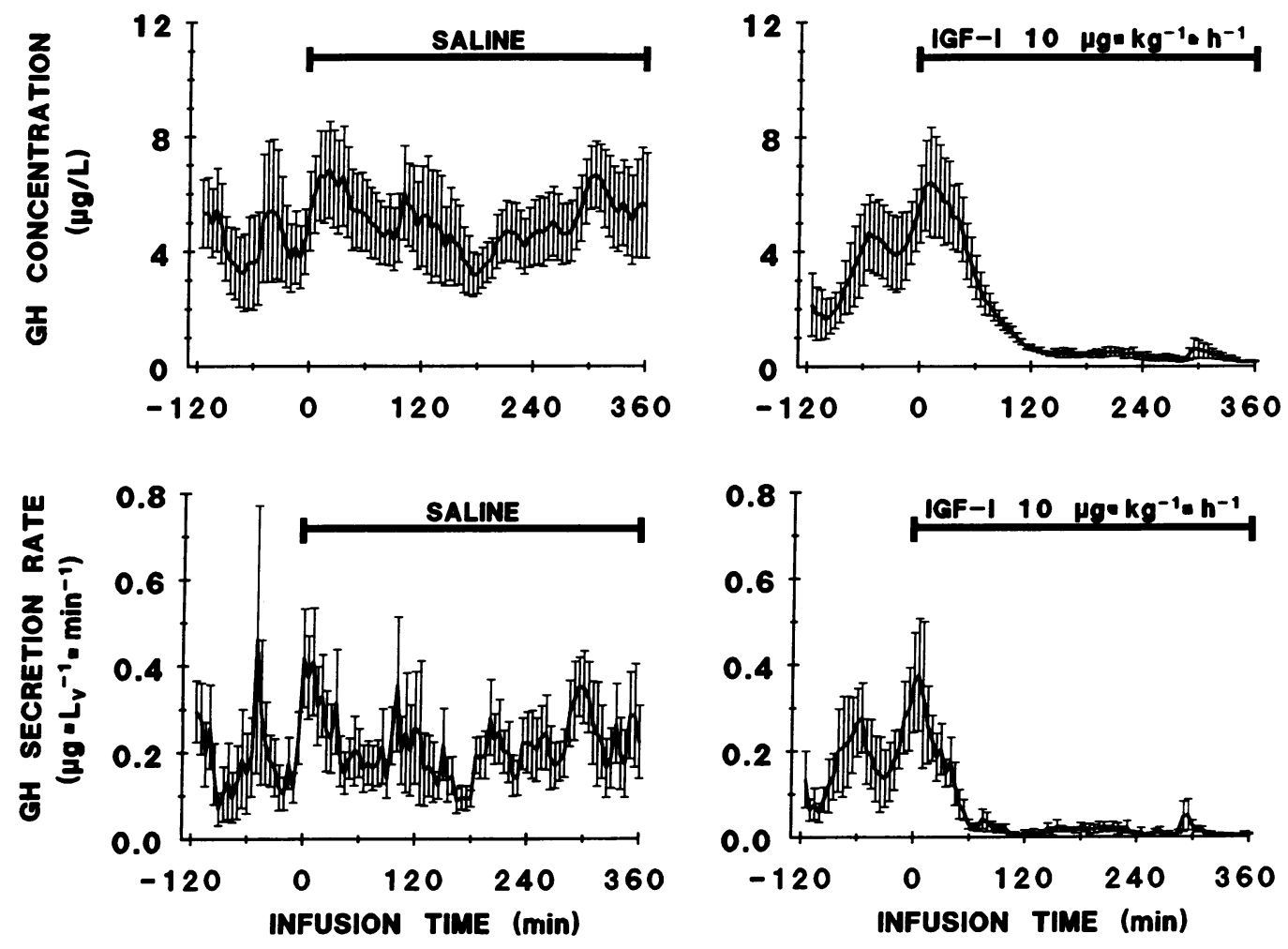

Figure 4. Mean ( \pm SE) serum

GH concentrations ( upper panels) and GH secretion rates ( $\mu \mathrm{g}$ per liter of distribution volume $\left[\mathrm{L}_{\mathrm{v}}\right]$ per $\mathrm{min}$ ) (lower panels), calculated by a waveform-independent deconvolution method (Methods), on the saline (left panels) and rhIGF-I (right pan$e l s$ ) days. Note that whereas pulsatile GH secretion remained elevated during saline (as expected for subjects fasted for 32-40 h ), rhIGF-I rapidly suppressed GH secretion rates during the first hour of rhIGF-I infusion.

the first $60 \mathrm{~min}$ of the rhIGF-I infusion. Fig. 5 illustrates 10 exponential decay curves fit to the individual GH secretion rates during the rhIGF-I infusion. This analysis revealed that GH secretion rates were suppressed by rhIGF-I with a $t_{1 / 2}$ of $16.6 \mathrm{~min}$ ( $67 \%$ confidence limits: $13.7-20.6 \mathrm{~min}$ ). It was not possible to fit exponential curves to the $\mathrm{GH}$ secretion rates during saline infusion since the disappearance rate constant approached zero. Thus, infusion of saline had no effect on $\mathrm{GH}$ secretion. As shown in Fig. 6, rhIGF-I reduced mean GH secretion rates fivefold during the 6-h period compared with saline

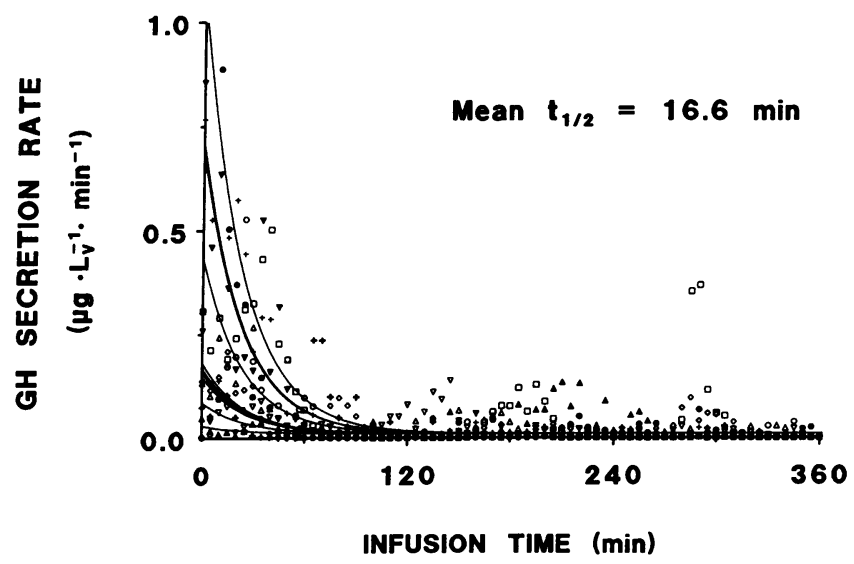

Figure 5. Group exponential analysis of $\mathrm{GH}$ secretion rates during the rhIGF-I infusions (Methods). The individual data points represent values for GH secretion rates for all 10 men, calculated by deconvolution analysis at each 5-min sampling point. Each curve represents the exponential decay of GH secretion rates for an individual. The rate constant for $\mathrm{GH}$ disappearance was constrained to be identical for all subjects so that a weighted mean half-time of disappearance could be calculated ( $16.6 \mathrm{~min} ; 67 \%$ confidence limits: $13.7-20.6$ ). $\left(0.21 \pm 0.045\right.$ vs. $\left.0.043 \pm 0.007 \mu \mathrm{g} \cdot \mathrm{L}_{\mathrm{v}}{ }^{-1} \cdot \mathrm{min}^{-1}, P \leq 0.01\right)$; decreases occurred in all 10 subjects. The suppression of $\mathrm{GH}$ secretion by rhIGF-I resulted primarily from an $84 \%$ reduction in the mass of $\mathrm{GH}$ secreted per pulse $(9.3 \pm 2.0$ [saline] vs. $1.5 \pm 0.56$ [rhIGF-I] $\mu \mathrm{g} / \mathrm{L}_{\mathrm{v}}, P \leq 0.01$ ) although the number of detectable $\mathrm{GH}$ pulses during the 6-h period also decreased by $32 \%(4.7 \pm 0.45$ [saline] vs. $3.2 \pm 0.53$ [rhIGF-I], $P \leq 0.05)$. There were no significant differences between pretreatment baseline periods for saline and rhIGF-I study days. Total and free IGF-I levels did not differ between subjects who had a decrease in the number of GH pulses and those who did not. $\mathrm{GH}$ secretion rates during the last $4 \mathrm{~h}$ of the rhIGF-I infusion were not correlated with total or free IGF-I concentrations.

Insulin and glucagon concentrations. Changes in insulin and glucagon concentrations during the rhIGF-I and saline infusions are shown in Fig. 7. Mean insulin concentrations were low (29-34 pmol/L) during the baseline periods as expected for subjects who had fasted for $32 \mathrm{~h}$. Mean insulin concentrations declined further during saline infusions as the fast continued but remained between 21 and 28 pmol/L. During rhIGF-I infusions, mean insulin concentrations decreased to a greater degree and by $60 \mathrm{~min}$ were significantly lower than during saline ( $28 \pm 3.2$ [saline] vs. $18 \pm 2.2 \mathrm{pmol} / \mathrm{L}$ [ rhIGF-I],$P<0.02)$. Mean insulin concentrations remained $\leq 18 \mathrm{pmol} / \mathrm{L}$ for the remainder of rhIGF-I infusion and were significantly lower than during saline except for between 180 and $240 \mathrm{~min}$ of the infusions. Mean glucagon concentrations increased slightly during saline infusion from $27 \pm 3.7 \mathrm{ng} / \mathrm{L}$ at the start of the baseline period to $46 \pm 6.3 \mathrm{ng} / \mathrm{L}$ at the end of the infusion. In contrast, glucagon levels decreased during rhIGF-I infusions and were significantly lower than during saline infusions by 45 $\min (32 \pm 5.4$ [saline] vs. $18 \pm 5.1$ [ $\mathrm{rhIGF}-\mathrm{I}] \mathrm{ng} / \mathrm{L}, P \leq 0.05)$. Mean glucagon concentrations remained $\leq 15 \mathrm{ng} / \mathrm{L}$ for the remainder of rhIGF-I infusion. 

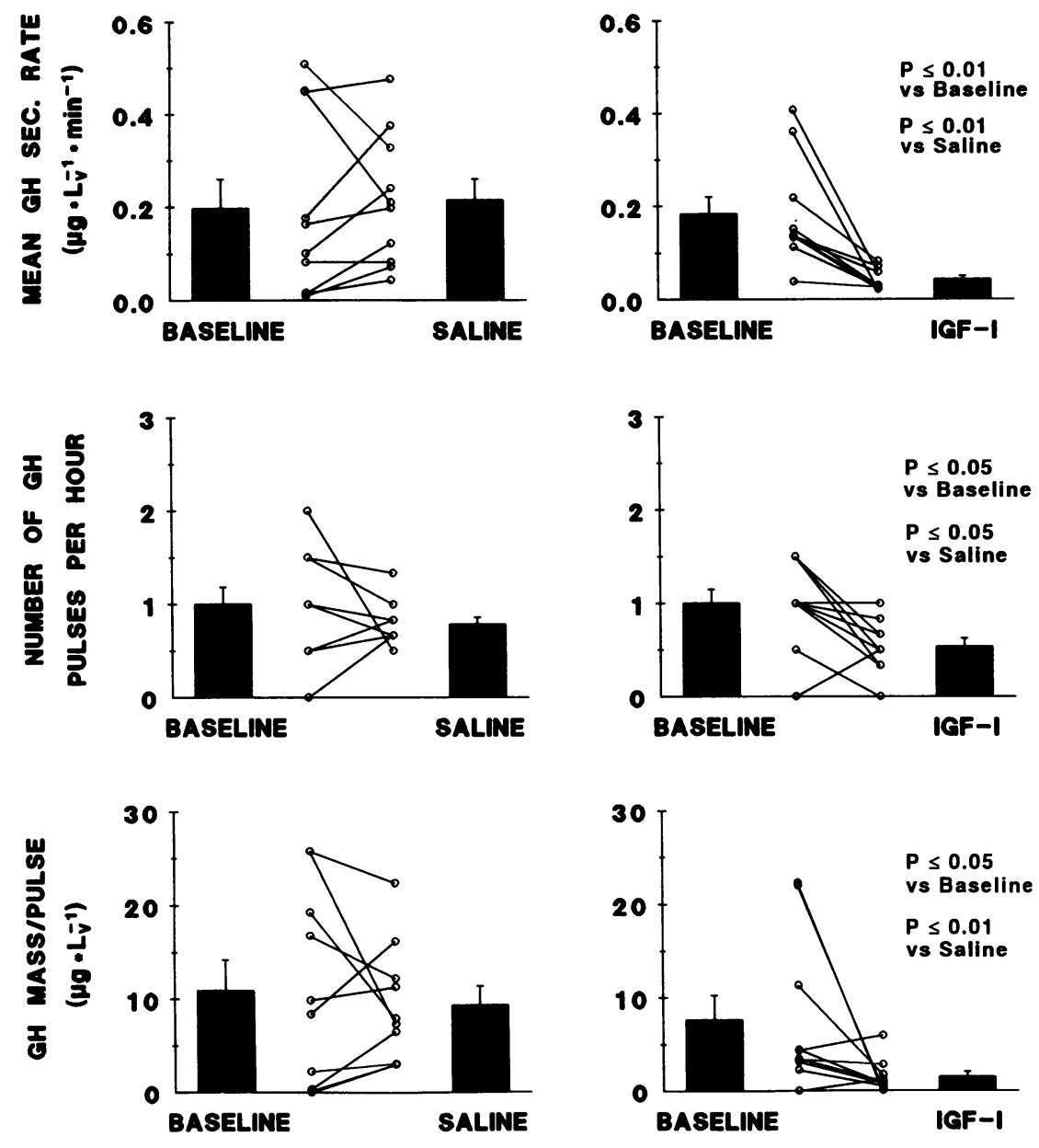

Figure 6. Attributes of pulsatile GH secretion during the saline (left panels) and rhIGF-I (right panels) infusions as calculated by a waveform-independent deconvolution algorithm (Methods). For each attribute, the baseline period (0800-1000 hours) and the infusion period (1000-1600 hours) are shown; bar graphs indicate mean $\pm \mathrm{SE}$ and line graphs illustrate individual differences between the baseline and infusion periods. Mean GH secretion rates per liter of distribution volume $\left(\mathrm{L}_{\mathrm{v}}\right)$ ( upper panel), the number of detectable GH secretory pulses during the 6-h infusion periods (middle panel), and the mass of $\mathrm{GH}$ secreted (per $\mathrm{L}_{\mathrm{v}}$ ) per pulse (lower panel) are shown. The Wilcoxon signed rank test was used to test for differences between the baseline and infusion periods and between the saline and rhIGF-I days.

FFA and ketoacid concentrations. From day 10800 hours ( $8 \mathrm{~h}$ of fasting) to the start of the infusions (day 21000 hours, $34 \mathrm{~h}$ of fasting) significant increases $(P \leq 0.01)$ in serum concentrations of FFA $(0.28 \pm 0.054$ vs. $0.96 \pm 0.097 \mathrm{mmol} / \mathrm{L})$, BOH $(0.042 \pm 0.013$ vs. $0.71 \pm 0.12 \mathrm{mmol} / \mathrm{L})$, and AcAc $(0.097 \pm 0.022$ vs. $0.31 \pm 0.047 \mathrm{mmol} / \mathrm{L})$ occurred in all $10 \mathrm{sub}-$ jects, confirming compliance with the fast. Changes in concentrations of FFA, BOH, and AcAc during the infusions are
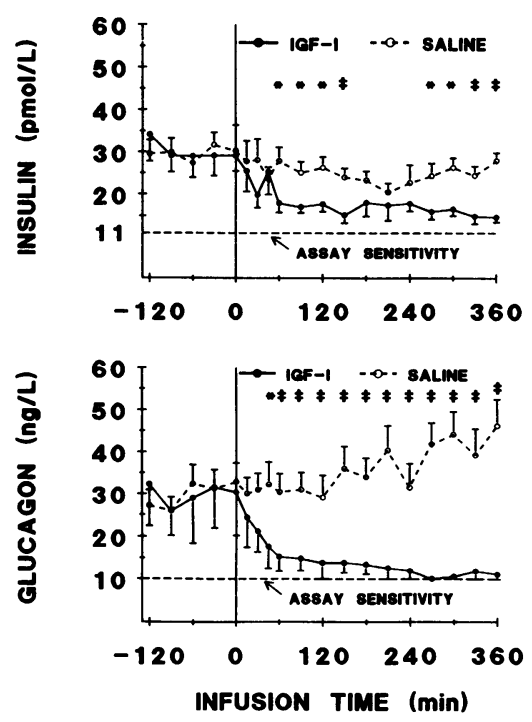

Figure 7. Mean ( \pm SE) plasma insulin (top) and glucagon (bottom) concentrations before and during the 6-h infusions of rhIGF-I $(\bullet)$ and saline (O). Data are presented as described in Fig. $1 .{ }^{*} P \leq 0.05 ; \ddagger P$ $\leq 0.01$. To convert $\mathrm{pmol} / \mathrm{L}$ insulin to $\mu \mathrm{U} /$ ml, multiply by 0.14 . shown in Fig. 8. During the first $3 \mathrm{~h}$ of saline and rhIGF-I infusions, FFA, BOH, and AcAc levels increased with no significant differences between the two infusions. However, after this time point FFA, BOH, and AcAc concentrations decreased for the remainder of rhIGF-I infusion whereas these levels continued to increase during the saline. Differences between the concentrations on rhIGF-I and saline days first became significant $(P \leq 0.05)$ by Wilcoxon signed rank test at $210 \mathrm{~min}$ for FFA, $270 \mathrm{~min}$ for $\mathrm{BOH}$, and $300 \mathrm{~min}$ for AcAc; these differences became progressively more significant by the end of the infusions $(P \leq 0.01)$.

Adverse effects of fasting and rhIGF-I. Serum concentrations of uric acid, creatinine, and bilirubin increased, and bicarbonate and glucose decreased during the 2-d fast as previously observed (22). A mild, reversible increase in serum transaminases occurred with fasting in one subject. The subjects experienced no adverse clinical effects from the rhIGF-I infusions. Small, asymptomatic decreases in plasma glucose concentrations $(0.25-0.50 \mathrm{mmol} / \mathrm{L})$ were observed in some subjects 30 min after discontinuing the rhIGF-I and glucose infusions. Thereafter, plasma glucose concentrations increased as the subjects were fed. No hypoglycemia occurred in overnight monitoring after the rhIGF-I infusions.

\section{Discussion}

This study demonstrates that fasting-enhanced pulsatile $\mathrm{GH}$ secretion in man is rapidly suppressed by a low-dose infusion of 

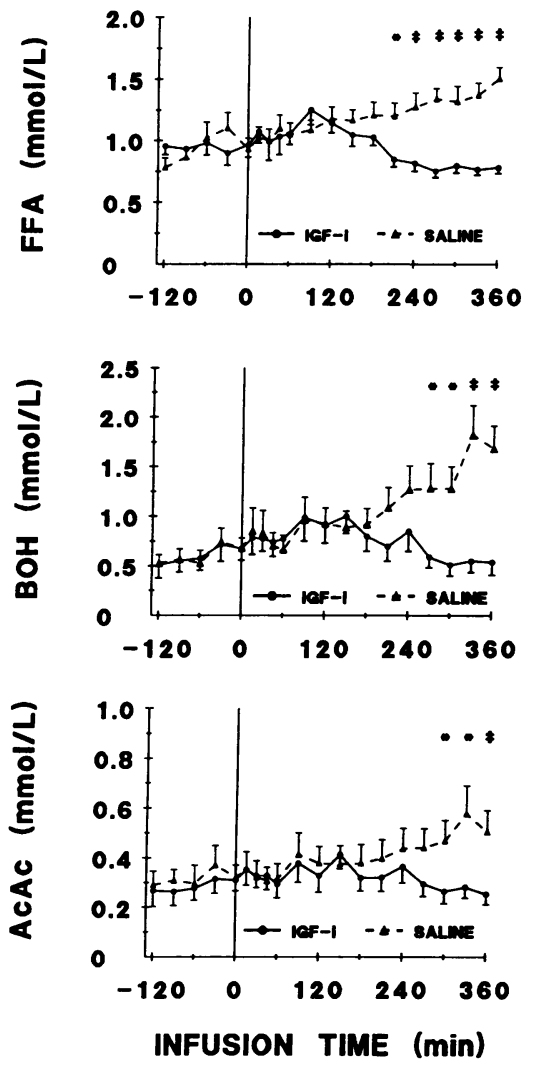

Figure 8. Mean ( $\pm \mathrm{SE})$ serum concentrations of FFA (top), $\beta$-hydroxybutyrate $(B O H$, middle), and acetoacetate (AcAc, bottom) before and during the 6-h infusions of rhIGF-I $(\bullet)$ and saline ( $\Delta$ ). Data are presented as described in Fig. $1 .{ }^{*} P \leq 0.05 ;{ }^{\ddagger} P$ $\leq 0.01$.

rhIGF-I when euglycemia is maintained. Deconvolution-resolved GH secretion rates decreased with a $t_{1 / 2}$ of $\sim 17 \mathrm{~min}$ after the start of the rhIGF-I infusion. By $60 \mathrm{~min}$ GH secretion rates were suppressed and remained so with only infrequent small pulses of secretion thereafter. Our exponential decay model likely overestimated the time to cellular response to rhIGF-I because: $(a)$ free IGF-I concentrations were rising during the first hour of the infusion; $(b)$ subpopulations of somatotrophs are differentially responsive to IGF-I (35); and (c) concurrent concentrations of GHRH and somatostatin modify the effect of IGF-I on GH secretion (36-38). Nevertheless, these studies establish that the negative feedback effects of rhIGF-I on GH secretion occurs within minutes in man.

The predominant effect of rhIGF-I on pulsatile GH secretion was to decrease the mass of $\mathrm{GH}$ secreted per pulse. Although the number of detectable $\mathrm{GH}$ pulses was also decreased by rhIGF-I, we cannot be certain that IGF-I regulates GH pulse frequency since serum $\mathrm{GH}$ concentrations below the limit of our immunoassay have been shown to be pulsatile in ultrasensitive GH assays (39). A primary effect of IGF-I on GH pulse amplitude was also observed in rats after ICV injections (9, 10). High concentrations of IGF-I receptors have been identified in the pituitary gland (40) as well as in the median eminence of the hypothalamus (41). Thus, in man, rhIGF-I likely decreases $\mathrm{GH}$ pulse amplitudes by interacting with pituitary IGF-I receptors and decreasing the somatotroph response to endogenous GHRH $(12,36-38)$. The effects of rhIGF-I on the hypothalamus are less clear from in vivo and in vitro studies with rats. Infusion of rhIGF-I may decrease GH pulse amplitudes by increasing hypothalamic somatostatin secretion (13, 14), perhaps in combination with endogenous IGF-II (11), and by decreasing GHRH secretion (15), although conflicting data on GHRH release have been reported $(14,15)$. Since some small GH pulses were observed after initial suppression of GH secretion by rhIGF-I, it is likely that the GH response to endogenous GHRH was not completely blocked by this dose of rhIGF-I.

The rapid suppression of $\mathrm{GH}$ secretion rates was closely associated with the rise in free IGF-I levels, suggesting that GH release was directly inhibited by binding of rhIGF-I to pituitary and/or hypothalamic IGF-I receptors (11-15, 35-38, 40, 41). Although it is possible that rhIGF-I suppressed GH secretion by reversing other fasting-induced hormonal and/or metabolic changes, this seems less likely in view of the known direct inhibitory effects of IGF-I on GH release in vitro $(12,35-38)$ and the rapid time course of the rhIGF-I effect. Enhanced IGF-I binding may have resulted from increased unbound IGF-I concentrations or alterations in circulating concentrations of IGFBPs (3). Under various in vitro conditions, IGFBPs have been shown to both potentiate and block IGF-I action (3). Prolonged rhIGF-I infusions (for 6-7 d) have previously been reported to increase concentrations of IGFBP-1, -2 , and -3 after $48 \mathrm{~h}(42,43)$. After single intravenous bolus injections of 30 $\mu \mathrm{g} / \mathrm{kg}$ rhIGF-I, Lieberman and colleagues (24) observed a transient increase in a 30-kD IGFBP, which most likely represented IGFBP-1 between 150 and $210 \mathrm{~min}$ after the injection; IGFBP-2, -3, and -4 were unaffected. Since IGFBP-1 crosses vascular endothelium (44), it is possible that increased association of plasma IGF-I with IGFBP-1 may increase the interaction of IGF-I with its receptor $(3,42,43)$. Frequent determinations of IGFBP concentrations during a rhIGF-I infusion might clarify the relative importance of changes in IGFBP concentrations in mediating the suppressive effects of rhIGF-I on GH secretion.

Several other investigators have infused rhIGF-I in humans to study its metabolic effects but we are aware of only two studies in which euglycemia was maintained and GH concentrations were measured $(18,19)$. In both studies, $\mathrm{GH}$ was measured only after prolonged infusions and with insufficient frequency to assess effects on pulsatile $\mathrm{GH}$ secretion. After $6 \mathrm{~d}$ of rhIGF-I infusion, Guler and colleagues (18) demonstrated decreased GHRH-stimulated GH release in one of two subjects and decreased spontaneous nocturnal GH release in one subject. Zenobi and co-workers (19) found that serum GH levels were lower in single samples obtained after 24,29 , and $33 \mathrm{~h}$ of rhIGF-I infusion compared with a saline control infusion. In the latter study, the differences were small since GH concentrations were also low on the saline control day (19), as is expected in fed subjects during the daytime $(8,21,22)$. Our data extend these observations by demonstrating the rapid and profound inhibitory effects of IGF-I on pulsatile GH secretion under conditions in which this effect could be optimally observed.

The minimum dose of rhIGF-I necessary to suppress GH secretion is not known. In our study, continuous infusion of 10 $\mu \mathrm{g} \cdot \mathrm{kg}^{-1} \cdot \mathrm{h}^{-1}$ for $6 \mathrm{~h}$ increased total IGF-I concentrations from $\sim 100$ to $300 \mu \mathrm{g} /$ liter, which is slightly above the normal range for our assay (31-240 $\mu \mathrm{g} /$ liter). Mean free IGF-I levels increased from $2.4 \pm 0.2$ during the baseline period to $9.9 \pm 3.5$ $\mu \mathrm{g} /$ liter after $3 \mathrm{~h}$ of rhIGF-I infusion and then remained between 8 and $9.5 \mu \mathrm{g} /$ liter for the remainder of the infusion. However, GH secretion rates were suppressed within the first $60 \mathrm{~min}$ of the infusion when total and free IGF-I levels were 1.6- and 2-fold above baseline levels, respectively. In the study 
of Zenobi et al. (19), baseline total and free IGF-I concentrations were $180-200$ and $10 \mu \mathrm{g} /$ liter, respectively, using different assay methods. Infusion of 7 and $14 \mu \mathrm{g} \cdot \mathrm{kg}^{-1} \cdot \mathrm{h}^{-1}$ increased total IGF-I levels to $\sim 560$ and $830 \mu \mathrm{g} /$ liter at $10 \mathrm{~h}$ and 740 and $900 \mu \mathrm{g} /$ liter at $33 \mathrm{~h}$ of infusion. Free IGF-I levels were $\sim 25$ and $140 \mu \mathrm{g} /$ liter at $10 \mathrm{~h}$ and 18 and $60 \mu \mathrm{g} /$ liter at $33 \mathrm{~h}$ for these two doses, respectively (19). Other studies have achieved higher total and free IGF-I concentrations using higher doses of rhIGF-I administered either as continuous infusions $(18,43$, $45)$ or boluses $(17,24,46)$. Thus, our study and that of Zenobi et al. (19) indicate that rhIGF-I infusions that increase total and free IGF-I levels two- to fourfold will suppress serum GH concentrations. Further studies will be required to determine if lower doses of rhIGF-I will suppress GH secretion.

Although glucose was infused to maintain euglycemia in our fasted subjects, only minimal amounts were infused during the first $60 \mathrm{~min}$ when $\mathrm{GH}$ secretion rates were decreasing. The amount of glucose infused corresponded to an hourly glucose dose for a typical $70-\mathrm{kg}$ man of 0.7 and $5.0 \mathrm{~g}$ during the first and last hours of the rhIGF-I infusion, respectively. For the entire 6 -h infusion, the total glucose dose was $\sim 20 \mathrm{~g}$ or $80 \mathrm{kcal}$, which is considerably less than the $2,400-2,500 \mathrm{kcal}$ ingested to maintain euglycemia during the continuous rhIGF-I infusions performed by Guler et al. (18) and Zenobi et al. (19). It is likely that glucose uptake was stimulated by rhIGF-I since plasma insulin concentrations were suppressed as previously reported $(18,19,24,45-47)$. Furthermore, IGF-I receptors are present in human skeletal muscle and IGF-I stimulates muscle glucose uptake in vitro with a similar dose-response curve as insulin (48). However, it is unlikely that glucose uptake was responsible for suppression of $\mathrm{GH}$ secretion since very little glucose was infused to maintain euglycemia during the first hour of the rhIGF-I infusion. In addition, preliminary data indicate that a low-dose euglycemic insulin infusion (steady state insulin concentrations $\approx 150 \mathrm{pmol} / \mathrm{L}$ or $21 \mu \mathrm{U} / \mathrm{ml}$ ) that stimulates twice as much glucose uptake as the present rhIGF-I infusion does not suppress spontaneous $\mathrm{GH}$ secretion during the first $4 \mathrm{~h}(49)$. Higher insulin levels $(\approx 400 \mathrm{pmol} / \mathrm{L})$ during euglycemic clamps resulted in variable suppression of the $\mathrm{GH}$ response to GHRH in five normal subjects, although this was not statistically significant ( 50 ). Thus, it seems likely that inhibition of $\mathrm{GH}$ secretion and stimulation of glucose uptake are independent actions of rhIGF-I and that lower doses of rhIGF-I would suppress $\mathrm{GH}$ secretion without stimulating glucose uptake.

In addition to the rapid decreases in $\mathrm{GH}$ and insulin levels, plasma glucagon concentrations were rapidly suppressed by rhIGF-I (within 1-2 h). Similarly, Boulware and colleagues (47) reported a $40 \%$ decrease in glucagon concentrations during a 3-h euglycemic infusion of rhIGF-I in man. Since euglycemia was maintained by a glucose clamp it is unlikely that the glucose infusion inhibited glucagon release. High affinity IGF-I receptors have been identified on rat pancreatic alpha and beta cells ( 51$)$. In studies with human fetal islet cell clusters in tissue culture and rat pancreas perifusion systems, IGF-I acutely decreased insulin secretion but had no effect on glucagon release (52-54). Thus, although it is likely that rhIGF-I has a direct inhibitory effect on beta cell insulin secretion, the mechanism by which rhIGF-I decreased glucagon concentrations is not known.

In rats, IGF-I infusions stimulated glucose uptake but had no effect on hepatic glucose production or circulating concen- trations of lipid metabolites $(55,56)$. This suggested that the metabolic effects of IGF-I are mediated by its own receptor and not the insulin receptor $(2,56)$. We measured serum concentrations of FFA, BOH, and AcAc to determine if this was also the case in man. Serum concentrations of FFA, BOH, and AcAc continued to rise during the first $3 \mathrm{~h}$ of the rhIGF-I infusion, as expected in subjects fasted for $34 \mathrm{~h}$. Since $\mathrm{GH}$ secretion was suppressed during this early time period this suggests that the inhibitory effect of rhIGF-I on GH secretion is independent of its insulin-like metabolic effects. However, during the last 3 $h$ of the rhIGF-I infusion serum FFA, BOH, and AcAc levels were partially suppressed. At the end of the 6-h infusion, concentrations of FFA, BOH, and AcAc were 52, 32, and $50 \%$ of their respective concentrations at the conclusion of the saline infusion. Similarly, Boulware and co-workers (47) administered rhIGF-I $12-24 \mu \mathrm{g} \cdot \mathrm{kg}^{-1} \cdot \mathrm{h}^{-1}$ for $3 \mathrm{~h}$ during a euglycemic clamp in postabsorptive subjects and observed significant decreases in serum concentrations of FFA and amino acids, as well as a $50-60 \%$ decrease in hepatic glucose production. The late decline in FFA, BOH, and AcAc levels during rhIGF-I infusion may reflect either suppression of lipolytic hormones (GH and glucagon) or a direct antilipolytic effect of IGF-I. In contrast to skeletal muscle glucose uptake, which is equally responsive to similar concentrations of IGF-I or insulin (48), human adipocytes require 800 -fold higher concentrations of IGF-I than insulin to stimulate half-maximal glucose uptake (57). Isolated human hepatocytes have very low levels of specific IGF-I binding (58). Thus, supraphysiologic free IGF-I levels attained late in the rhIGF-I infusion may have activated insulin receptors to inhibit lipolysis although a role for IGF-I receptors cannot be excluded.

The mechanisms responsible for enhanced GH secretion with fasting are not known. Since prolonged fasting decreases total IGF-I concentrations (59), a reduction in negative feedback on $\mathrm{GH}$ is possible. However, in this study and in our previous studies $(21,22)$, increases in pulsatile GH secretion occurred before significant decreases in total IGF-I levels. Of interest, the time course of suppression of fasting-enhanced GH secretion by rhIGF-I is virtually identical to that of refeeding with balanced eucaloric meals (60). This suggests that similar changes in free IGF-I occur in both experimental paradigms. Since IGFBP-1 concentrations are increased by fasting and decrease rapidly after refeeding $(3,59)$, rapid changes in IGFBP-1 concentrations may mediate the effects of nutrition on $\mathrm{GH}$ secretion by altering the unbound concentrations of IGF-I.

In conclusion, fasting-enhanced $\mathrm{GH}$ secretion is rapidly suppressed by a low-dose euglycemic IGF-I infusion that stimulates minimal glucose uptake while decreasing insulin and glucagon levels. The predominant effect of IGF-I is to decrease the mass of GH secreted per secretory pulse. Delayed suppression of lipid metabolites may reflect decreases in GH and glucagon concentrations or a direct effect of IGF-I. The rhIGF-I infusion suppressed fasting-enhanced $\mathrm{GH}$ secretion with a similar time course as refeeding, suggesting that changes in plasma concentrations of free IGF-I and/or IGFBPs mediate the effects of nutrition on $\mathrm{GH}$ secretion.

\section{Acknowledgments}

We thank Ms. Sandra W. Jackson and the staff of the General Clinical Research Center for their expert assistance. We also thank Dr. David A. 
Krusch for providing the computer program for euglycemic clamps, Ms. Ginger Bauler and Ms. Catherine Kern for performing the GH assays, Ms. Martha MacLeod and Mr. George Vandenhoff for performing the insulin and glucagon assays, Dr. J. D. Veldhuis and Dr. M. L. Johnson for providing the waveform-independent deconvolution computer program, Dr. Robert Abbott for assistance with statistical analysis, and Mr. David Boyd for assistance with CLINFO.

This work was supported by National Institutes of Health grants RR-00847 (to the University of Virginia General Clinical Research Center), Clinical Investigator Award 1-K08-HD-00860 ( to M. L. Hartman), DK-32632 (to M. O. Thorner), DK-38942 (to the University of Virginia Diabetes Endocrinology Research Center), and the University of Virginia NSF Science and Technology Center for Biological Timing. Dr. Clayton was supported by the Medical Research Council of the United Kingdom.

\section{References}

1. Daughaday, W. H., and P. Rotwein. 1989. Insulin-like growth factors I and II. Peptide, messenger ribonucleic acid and gene structures, serum, and tissue concentrations. Endocr. Rev. 10:68-91.

2. Lowe, Jr., W. L. 1991. Biological actions of the insulin-like growth factors. In Insulin-like Growth Factors: Molecular and Cellular Aspects. D. LeRoith, editor. CRC Press, Boca Raton, FL. 49-85.

3. Clemmons, D. R. 1991. Insulin-like growth factor binding proteins. In Insulin-like Growth Factors: Molecular and Cellular Aspects. D. LeRoith, editor. CRC Press, Boca Raton, FL. 151-179.

4. Casanueva, F. F. 1992. Physiology of growth hormone secretion and action. Endocrinol. Metab. Clin. North Am. 21:483-517.

5. Tannenbaum G. S. 1989. Interrelation of growth hormone-releasing hormone and somatostatin in the regulation of growth hormone secretion. In Hormonal Regulation of Growth. H. Frisch and M. O. Thorner, editors. Raven Press, New York. 1-17.

6. Frohman, L. A., T. R. Downs, I. J. Clarke, and G. B. Thomas. 1990 Measurement of growth hormone-releasing hormone and somatostatin in hypothalamic-portal plasma of unanesthetized sheep: spontaneous secretion and response to insulin-induced hypoglycemia. J. Clin. Invest. 86:17-24.

7. Thorner, M. O., M. L. Vance, M. L. Hartman, R. W. Holl, W. S. Evans, J. D. Veldhuis, E. Van Cauter, G. Copinschi, and C. Y. Bowers. 1990. Physiological role of somatostatin on growth hormone regulation in humans. Metab. Clin. Exp. 39(Suppl 2):40-42.

8. Hartman, M. L., A. C. S. Faria, M. L. Vance, M. L. Johnson, M. O. Thorner, and J. D. Veldhuis. 1991. Temporal structure of in vivo growth hormone secretory events in humans. Am. J. Physiol. 260:E101-E110.

9. Tannenbaum, G. S., H. J. Guyda, and B. I. Posner. 1983. Insulin-like growth factors: a role in growth hormone negative feedback and body weight regulation via brain. Science (Wash. DC). 220:77-79.

10. Abe, H., M. E. Molitch, J. J. Van Wyk, and L. E. Underwood. 1983. Human growth hormone and somatomedin-C suppress the spontaneous release of growth hormone in unanesthetized rats. Endocrinology. 113:1319-1324.

11. Harel, Z., and G. S. Tannenbaum. 1992. Synergistic interaction between insulin-like growth factors-I and -II in central regulation of pulsatile growth hormone secretion. Endocrinology. 131:758-764.

12. Yamashita, S., and S. Melmed. 1986. Insulin-like growth factor I action on rat anterior pituitary cells: suppression of growth hormone secretion and messenger ribonucleic acid levels. Endocrinology. 118:176-182.

13. Berelowitz, M., M. Szabo, L. A. Frohman, S. Firestone, L. Chu, and R. L. Hintz. 1981. Somatomedin-C mediates growth hormone negative feedback by effects on both the hypothalamus and the pituitary. Science (Wash. DC). 212:1279-1281.

14. Aquila, M. C. 1991. Insulin-like growth factor I (IGF-I) regulates somatostatin (SRIF) release, messenger ribonucleic acid levels in the rat hypothalamus. Prog. 73rd Meet. Endocr. Soc. 351. (Abstr. 1283).

15. Shibasaki, T., N. Yamauchi, M. Hotta, A. Masuda, T. Imaki, H. Demura, N. Ling, and K. Shizume. 1986. In vitro release of growth hormone-releasing factor from rat hypothalamus: effect of insulin-like growth factor-I. Regul. Pept. 15:47-53.

16. Sato, M., and L. A. Frohman. 1992. Differential effects of central and peripheral administration of GH and IGF-I on hypothalamic GH-releasing hormone (GRH) and somatostatin (SRIH) gene expression in the GH-deficient dwarf $(d w)$ rat. Prog. 74th Meet. Endocr. Soc. 446. (Abstr. 1580).

17. Guler, H.-P., J. Zapf, and E. R. Froesch. 1987. Short-term metabolic effects of recombinant human insulin-like growth factor I in healthy adults. $N$. Engl. J. Med. 317:137-140.

18. Guler, H.-P., C. Schmid, J. Zapf, and E. R. Froesch. 1989. Effects of recombinant insulin-like growth factor I on insulin secretion and renal function in normal human subjects. Proc. Natl. Acad. Sci. USA. 86:2868-2872.
19. Zenobi, P. D., S. Graf, H. Ursprung, and E. R. Froesch. 1992. Effects of insulin-like growth factor I on glucose tolerance, insulin levels, and insulin secretion. J. Clin. Invest. 89:1908-1913.

20. DeFronzo, R. A., J. D. Tobin, and R. Andres. 1979. Glucose clamp technique: a method for quantifying insulin secretion and resistance. Am. $J$. Physiol. 237:E214-E223.

21. Ho, K. Y., J. D. Veldhuis, M. L. Johnson, R. Furlanetto, W. S. Evans, K. G. M. M. Alberti, and M. O. Thorner. 1988. Fasting enhances growth hormone secretion and amplifies the complex rhythms of growth hormone secretion in man. J. Clin. Invest. 81:968-975.

22. Hartman, M. L., J. D. Veldhuis, M. L. Johnson, M. M. Lee, K. G. M. M. Alberti, E. Samojlik, and M. O. Thorner. 1992. Augmented growth hormone (GH) secretory burst frequency and amplitude mediate enhanced GH secretion during a two day fast in normal men. J. Clin. Endocrinol. Metab. 74:757-765.

23. Veldhuis, J. D., and M. L. Johnson. 1992. Deconvolution analysis of hormone data. Methods Enzymol. 210:539-575.

24. Lieberman S. A., J. Bukar, S. A. Chen, A. C. Celniker, P. G. Compton, J. Cook, J. Albu, A. J. Perlman, and A. R. Hoffman. 1992. Effects of recombinant human insulin-like growth factor-I (rhIGF-I) on total and free IGF-I concentrations, IGF-binding proteins, and glycemic response in humans. J. Clin. Endocrinol. Metab. 75:30-36.

25. Daughaday, W. H., I. K. Mariz, and S. L. Blethen. 1980. Inhibition of access of bound somatomedin to membrane receptor and immunobinding sites: a comparison of radioreceptor and radioimmunoassay of somatomedin in native and acid-ethanol-extracted serum. J. Clin. Endocrinol. Metab. 51:781-788.

26. Freedlender, A. E., G. E. Vandenhoff, M. S. MacLeod, and R. R. Malcolm. 1984. Radioimmunoassay of insulin. In Methods in Diabetes Research. Vol. 1B. J. Larner and S. L. Pohl, editors. John Wiley \& Sons, New York. 295305

27. Von Schenck, H. 1984. Radioimmunoassay of glucagon. In Methods in Diabetes Research. Vol. 1B. J. Larner and S. L. Pohl, editors. John Wiley \& Sons, New York. 327-345

28. Harrison, J., A. W. Hodson, A. W. Skillen, R. Stappenbeck, L. Agius, and K. G. M. M. Alberti. 1988. Blood glucose, lactate, pyruvate, 3-hydroxybutyrate and acetoacetate measurements in man using a centrifugal analyzer with fluorimetric attachment. J. Clin. Chem. Clin. Biochem. 26:141-146.

29. Knox, D. P., and D. G. Jones. 1984. Automated enzymatic determination of plasma free fatty acids by centrifugal analysis. J. Automatic Chem. 6:152-154.

30. Hartman, M. L., J. D. Veldhuis, M. L. Vance, A. C. S. Faria, R. W. Furlanetto, and M. O. Thorner. 1990. Somatotropin pulse frequency and basal concentrations are increased in acromegaly and are reduced by successful therapy. J. Clin. Endocrinol. Metab. 70:1375-1384.

31. Faria, A. S. C., J. D. Veldhuis, M. O. Thorner, and M. L. Vance. 1989. Half-time of endogenous growth hormone (GH) disappearance in normal man after stimulation of GH secretion by GH-releasing hormone and suppression with somatostatin. J. Clin. Endocrinol. Metab. 68:535-541.

32. Johnson, M. L., and S. G. Frazier. 1985. Non-linear least-squares analysis. Methods Enzymol. 117:301-342.

33. Daniel, W. W. 1987. Biostatistics: A Foundation for Analysis in the Health Sciences. John Wiley \& Sons, New York.

34. O'Brien, P. C., and M. A. Shampo. 1988. Statistical considerations for performing multiple tests in a single experiment. 3. Repeated measures over time. Mayo Clin. Proc. 63:918-920.

35. Hoeffler, J. P., S. A. Hicks, and S. L. Frawley. 1987. Existence of somatotrope subpopulations which are differentially responsive to insulin-like growth factor I and somatostatin. Endocrinology. 120:1936-1941.

36. Ceda, G. P., R. G. Davis, R. G. Rosenfeld, and A. R. Hoffman. 1987. The growth hormone (GH)-releasing hormone (GHRH)-GH-somatostatin axis: evidence for rapid inhibition of GHRH-elicited GH release by insulin-like growth factors I and II. Endocrinology. 120:1658-1662.

37. Lamberts, S. W. J., F. Den Holder, and L. J. Hofland. 1989. The interrelationship between the effects of insulin-like growth factor I and somatostatin on growth hormone secretion by normal rat pituitary cells: the role of glucocorticoids. Endocrinology. 124:905-911.

38. Namba H., S. Morita, and S. Melmed. 1989. Insulin-like growth factor-I action on growth hormone secretion and messenger ribonucleic acid levels: interaction with somatostatin. Endocrinology. 124:1794-1799.

39. Winer, L. M., M. A. Shaw, and G. Baumann. 1990. Basal plasma growth hormone levels in man: new evidence for rhythmicity of growth hormone secretion. J. Clin. Endocrinol. Metab. 70:1678-1686.

40. Rosenfeld, R. G., G. Ceda, D. M. Wilson, L. A. Dollar, and A. R. Hoffman. 1984. Characterization of high affinity receptors for insulin-like growth factors I and II on rat anterior pituitary cells. Endocrinology. 114:1571-1575.

41. Werner, H., M. Woloschak, B. Stannard, Z. Shen-Orr, C. T. Roberts, Jr., and D. LeRoith. 1991. The insulin-like growth factor I receptor: molecular biology, heterogeneity, and regulation. In Insulin-like Growth Factors: Molecular and Cellular Aspects. D. LeRoith, editor. CRC Press, Boca Raton, FL. 17-47.

42. Zapf, J., C. Schmid, H. P. Guler, M. Waldvogel, C. Hauri, P. Hossenlopp, M. Binoux, and E. R. Froesch. 1990. Regulation of binding proteins for insulinlike growth factors (IGF) in humans: increased expression of IGF binding protein 
2 during IGF I treatment of healthy adults and in patients with extrapancreatic tumor hypoglycemia. J. Clin. Invest. 86:952-961.

43. Young, S. C. J., L. E. Underwood, A. Celniker, and D. R. Clemmons. 1992. Effects of recombinant insulin-like growth factor-I (IGF-I) and growth hormone on serum IGF-binding proteins in calorically restricted adults. J. Clin. Endocrinol. Metab. 75:603-608.

44. Bar, R. S., M. Boes, D. R. Clemmons, W. H. Busby, A. Sandra, B. L. Dake, and B. A. Booth. 1990. Insulin differentially alters transcapillary movement of intravascular IGFBP-1, IGFBP-2 and endothelial cell IGF-binding proteins in the rat heart. Endocrinology. 127:497-499.

45. Clemmons, D. R., A. Smith-Banks, and L. E. Underwood. 1992. Reversal of diet-induced catabolism by infusion of recombinant insulin-like growth factorI in humans. J. Clin. Endocrinol. Metab. 75:234-238.

46. Takano, K., N. Hizuka, K. Shizume, K. Asakawa, I. Fukuda, and H. Demura. 1991. Repeated sc administration of recombinant human insulin-like growth factor I (IGF-I) to human subjects for 7 days. Growth Regul. 1:23-28.

47. Boulware, S. D., N. J. Rennert, L. S. Matthews, W. V. Tamborlane, and R. S. Sherwin. 1991. The scope of IGF-I's actions in humans extend to carbohydrate, protein and lipid metabolism. Prog. 73rd Meet. Endocr. Soc. 434. (Abstr. 1613).

48. Dohm, G. L., C. W. Elton, M. S. Raju, N. D. Mooney, R. DiMarchi, W. J. Pories, E. G. Flickinger, S. M. Atkinson, and J. F. Caro. 1990. IGF-I-stimulated glucose transport in human skeletal muscle and IGF-I resistance in obesity and NIDDM. Diabetes. 39:1028-1032.

49. Hartman, M. L., and P. E. Clayton. 1992. IGF-I suppression of pulsatile $\mathrm{GH}$ secretion is not mediated by glucose uptake in man. Prog. 74th Meet. Endocr. Soc. 321. (Abstr. 1080).

50. Press, M., S. Caprio, W. V. Tamborlane, R. Bhushan, M. Thorner, W. Vale, J. Rivier, and R. S. Sherwin. 1992. Pituitary responses to growth hormonereleasing hormone in IDDM: abnormal responses to insulin and hyperglycemia. Diabetes. 41:17-21.

51. Van Schravendijk, C. F. H., A. Foriers, J. L. Van den Brande, and D. G.
Pipeleers. 1987. Evidence for the presence of type 1 insulin-like growth factor receptors on rat pancreatic A and B cells. Endocrinology. 121:1784-1788.

52. Otonkoski, T., M. Knip, I. Wong, and O. Simell. 1988. Effects of growth hormone and insulin-like growth factor I on endocrine function of human fetal islet-like cell clusters during long-term tissue culture. Diabetes. 37:1678-1683.

53. Kawai, K., S. Suzuki, K. Takano, N. Hizuka, Y. Watanabe, and K. Yamashita. 1990. Effects of insulin-like growth factor-I on insulin and glucagon release from isolated perfused rat pancreas. Endocrinol. J. 37:867-874.

54. Leahy, J. L., and K. M. Vandekerkhove. 1990. Insulin-like growth factor-I at physiological concentration is a potent inhibitor of insulin secretion. Endocrinology. 126:1593-1598.

55. Zapf, J., C. Hauri, M. Waldvogel, and E. R. Froesch. 1986. Acute metabolic effects and half-lives of intravenously administered insulin-like growth factors I and II in normal and hypophysectomized rats. J. Clin. Invest. 77:17681775.

56. Jacob, R., E. Barrett, G. Plewe, K. D. Fagin, and R. S. Sherwin. 1989. Acute effects of insulin-like growth factor I on glucose and amino acid metabolism in the awake fasted rat. J. Clin. Invest. 83:1717-1723.

57. Sinha, M. K., C. Buchanan, N. Leggett, L. Martin, P. G. Khazanie, R. DiMarchi, W. J. Pories, and J. F. Caro. 1989. Mechanism of IGF-I-stimulated glucose transport in human adipocytes: demonstration of specific IGF-I receptors not involved in stimulation of glucose transport. Diabetes. 38:1217-1225.

58. Caro, J. F., J. Poulos, O. Ittoop, W. J. Pories, E. G. Flickinger, and M. K. Sinha. 1988. Insulin-like growth factor I binding in hepatocytes from human liver, human hepatoma, and normal, regenerating, and fetal liver. J. Clin. Invest. 81:976-981.

59. Clemmons, D. R., and L. E. Underwood. 1991. Nutritional regulation of IGF-I and IGF binding proteins. Annu. Rev. Nutr. 11:393-412.

60. Hartman, M. L., and M. O. Thorner. 1990. Fasting-induced enhancement of pulsatile growth hormone $(\mathrm{GH})$ secretion is rapidly abolished by refeeding. Prog. 72nd Meeting of the Endocrine Soc. 55. (Abstr. 123). 